\title{
Adopting of balanced scorecard by manufacturing firms in Bahrain: An empirical study
}

\author{
Ali Gaber Saleh Mahmoud
}

Department of Accounting, Faculty of Commerce, Tanta University, Egypt and currently, Seconded Assistant Professor, Department of Accounting, College of Business Administration, University of Bahrain, Kingdom of Bahrain

Email address:

ali_mahmoud819@yahoo.com

\section{To cite this article:}

Ali Gaber Saleh Mahmoud. Adopting of Balanced Scorecard by Manufacturing Firms in Bahrain: An Empirical Study. Journal of Finance and Accounting. Vol. 2, No. 3, 2014, pp. 53-61. doi: 10.11648/j.jfa.20140203.14

\begin{abstract}
Performance measurements play an important role in understanding the determinants of successful performance of firms. The balanced scorecard is one of the integrated performance measurement systems that has wide acceptance in several countries. The prior studies investigated different aspects of balanced scorecard in the developed countries, but this study contributes to the performance measurement literature by collecting evidence about the extent of adoption the balanced scorecard in one of the developing countries such as Bahrain. Also, this study statistically examined the effect of a firm's size on adopting balance scorecard. The main instrument in surveying the Bahrain firms is a questionnaire. The findings rejected the null hypotheses. It is found statistically that there are differences between Bahraini manufacturing firms in adopting the balanced scorecard. Also the study found that there is effect of the firm's size with the growing use of non-financial measures by the BSC adopters.
\end{abstract}

Keywords: Balanced Scorecard, Performance Measurement, Bahrain

\section{Introduction}

Improving the performance of firms is a major challenge, particularly for developing countries. The traditional performance measurement systems are criticized by Kaplan, R. S. \& Norton, D. P. (1992) because they are based on long production runs and mass production with known characteristics and a stable technology. In this stable environment, the uncertainty in demand, actual costs, and delivery times, were accepted as given variables and could not be changed. To be competitive in the new environment, firms must produce products of substantially higher quality with greatly reduced inventory levels, and production runs, reduce set-up times, increase manufacturing flexibility, and reduce randomness caused by uncertain supply, poor quality, and the overall production process. Traditional performance measures are not relevant in this new environment. The challenge is to devise new internal accounting systems that will be supportive of the firm's new strategy. Improving the performance measures of quality, inventory performance, productivity, flexibility, and innovation will be required. Managerial performance measures based on achieving these strategic goals should be developed to replace the current emphasis on short-term financial performance measures. Performance measures can play the key role in initiating or implementing technological innovations and organizational change through incentives for improving performance and measurements to evaluate progress toward this goal. Balanced scorecard developed a multiple dimensional performance system by supplementing more traditional financial measures with non-financial measures, specifically with measures oriented toward customers, internal business processes and learning and growth activities. Balanced scorecard based on performance measurement systems have an important role in management as they serve as a link between the various units of an organization and facilitate higher management's propagation of plans and goals (which are linked to the overall strategy) throughout the organization.

\section{Review of Literature}

\subsection{Performance Measurement and Motivation for Adopting Balanced Scorecard}

Balanced scorecard was developed by Kaplan and Norton to measure the performance of firms (1992, 1993, 
1996, 2000, 2005, 2006 and 2008). Kaplan (2005). The balanced scorecard is widely implemented in various organizations in many countries. In the developed countries, many prior studies investigated the balanced scorecard, but few studies dealt with this phenomena in the developing countries. In these studies balanced scorecard was applied as a multidimensional performance measurement system. For example, evidence was presented in Hayes (1981) and Schonberger (1982) that many of the successful practices such as balanced scorecard in Japan require only a management commitment to improve manufacturing performance. There is a growing interest in the use of balanced scorecard in the Western firms. For example, in the UK, Bhimani (1994) and Dugdale (1994) indicated that firms were quite sensitive to the use of non-financial measures in performance evaluation. Marr and Schiuma (2003), conducted a survey about the extent of adoption of the balanced scorecard. They concluded that the balanced scorecard seems to be one of the most influential concepts in the field of performance management and measurement (PMM). Also, Downing (2001) stated that by the middle of 2001 , over $50 \%$ of the surveyed firms worldwide had adopted the balanced scorecard along with a further $25 \%$ considering its adoption. Silk (1998) suggested that around $60 \%$ of the Fortune 1000 firms in the US have adopted the balanced scorecard. Malmi (2001) found high levels of adoption within Finnish businesses. More recently, Rigby (2011) also found that $54 \%$ of the 1,230 global firms sampled had reported the use of the balanced scorecard. Taylor and Baines' study (2012), which assessed the reasons why UK universities are increasingly making use of strategic management tools such as the balanced scorecard. These prior studies showed to what extent the balanced scorecard has become popular. Neely, Gregory and Platts (1995) were examined the balance scorecard as a performance measurement system at three levels, firstly at the level of individual performance measures, secondly at the level of the set of performance measures and thirdly the relationship of this system with the environment in which it operates. Kollberg et al., (2005) were examined the roles of balanced scorecard in industrial and professional organizations. They concluded that balanced scorecard help management to follow up, coordinate, control, and improve certain aspects of organizational activities. Banchieri et al. (2011) determined the conditions under which the causal relationships between performance measures and they classified these measures into several types in association with employees' incentives. Speckbacher et al. (2003) used components (strategic objectives, targets or action plans, cause-and-effect relationships), in association of balanced scorecard with incentives, level of balanced scorecard implementation (corporate, business unit, plant, department, team, individual). They found motivation for using balanced scorecard and expected benefits and reasons for not implementing balanced scorecard. As for evaluation of balanced scorecard systems Burkert et al. (2010) were concluded firstly improvement of companies' general management practices, including an overall performance measurement system which is associated with specific management practices such as communication of strategy and monitoring of objectives achievement. Secondly achievement of organizational performance outcomes is linked with satisfaction of employees with the system. Therefore, the first null hypothesis is formulated as follows:

H1 There is no statistically significant difference between manufacturing firms in Bahrain to adopt balanced scorecard.

\subsection{Performance MEASUREMENT and Firm Size}

In the literature, prior studies indicated that balanced scorecard has been applied in many different sizes-firms. For example, It has also been applied not only in large organizations, but in SME's (Fernandes et al., 2006; Manville, 2007) as well. Merchant (1981) was argued that the bigger firms are more likely to adopt sophisticated management control systems. On the subject of balanced scorecard, Hoque and James (2000) concluded that the overall use of balanced scorecard measures is positively associated with bigger firms. Also, Speckbacher et al. (2003) found that there is a significant association between firm's size and adopting a balanced scorecard. Other studies, for example, Gumbus and Lussier (2006) and Philips et al. (2003) indicated that that there is a need to adopt balanced scorecard in the small and medium firms. Furthermore, Burkert et al. (2010) examined the effect of contextual variables on performance, such as firm's size and environmental uncertainty and internal factors like attitude toward new management tools and measurement practices. Hoque and James (2000) argued that large and complex firms that deal with an increased number of stakeholders, are likely to adopt more comprehensive measurement systems that enable them to measure multiple dimensions of organizational performance, including both financial and non-financial measures. Small and medium firms are likely to place greater emphasis on financial measures in their performance measurement system. They indicated that these results because these firms do not have the same pressures as large firms to meet the requirements and expectations of different stakeholder groups. In addition, Hvolby and Thorstenson (2001) indicated that financial measures are also likely to be more appealing to managers of the small and medium firms because these measures are available at a minimum cost and effort, generally relying on information which is readily provided by their financial accounting system. In addition, Perera and Baker (2007) reported that the small and medium firms have less need to develop and implement sophisticated measurement systems like balanced scorecard because managers of such firms are often able to manage the operational activities of the firms by themselves and take the necessary actions. Therefore, they place a significantly greater reliance on financial measures of firm performance. Therefore, the second null hypothesis is formulated as follows: 
H2 There is no statistically significant difference in adopting balance scorecard measures based on the firm size in Bahrain.

\section{Competitive Environment in Bahrain}

Bahrain is an emerging economy with a business environment that differs markedly from that in the other developing countries. Bahrain firms are moving rapidly into high technology products and services. The Bahrain manufacturing sector is very open and operates in a highly liberalized environment because it is exempted from the strict government policies. Bahrain firms are organized by the Ministry of Commerce and Industry Guidelines which encourage investment in Bahrain. The removal of price control constraints and liberation in all sub-sectors has provided competitive strength. A number of Bahrain firms gain competitive advantage through lower production costs, as raw materials and labor are available at lower costs than competitors in other countries. Another additional competitive advantage is the economic and political stability in the Gulf region. Further, market-based economy in Bahrain is supported by government policies in terms of liberal equity policy, employment of expatriates, and attractive tax incentives, provide businesses with the opportunity for growth and success. Bahrain has also moved towards a knowledge-based economy that allows firms to transact business in an environment that is geared towards information technology and educated and trainable workforce. The manufacturing industry in Bahrain is viewed as a particularly relevant area of study because of the use of new and advanced manufacturing environment and recent trends of measuring manufacturing performance,. Further, the use of performance measures are expected to be more diverse and extensive in manufacturing industries as compared to service or other types of industries. In addition, the manufacturing sectors in Bahrain are growing and plays a central role in the Bahrain economy because it is the second largest sector (after services) in terms of its share of total GDP where it contributed 34.3 percent in 2012.

\section{Research Methodology and Research Objectives}

This study aims to:

1. Collect evidence about the extent of adopting a balanced scorecard in Bahrain firms.

2. Determine effect of the firm's size on adopting balanced scorecard in Bahrain firms.

A total of 90 firms was randomly selected from the directory of the Ministry of Commerce and Industry (MCI) in Bahrain as listed in 2012. The MCI has consistently led Bahrain firms in the growth and modernization. The directory lists manufacturing firms of varying sizes. Firms chosen are from various industries and are located throughout Bahrain. Only firms with at least 25 employees were included in the target sample in order to have enough firms representing small, medium and large firms. A total of 83 firms requested the questionnaire. The questionnaire together with a cover letter was sent by e-mail to the chief executive officers (CEOs) and controllers. They are deemed to be the most appropriate personnel because of their diverse backgrounds and varied responsibilities, involving with strategy making and overall policies of the firms such as controlling and decision making. They also have responsibility for the performance of their firms. Of the 83 questionnaires e-mailed, a total of 79 were returned making a response rate of 87.8 percent. However, ten questionnaires were incomplete and excluded and only 69 responses were usable, resulting in a usable response rate of 76.7 percent. Of those responding, CEOs represent 34 percent in the target sample, while the remaining 66 percent served by financial controllers. The majority of respondents have old experience in their present position for at least five years. The questionnaire was organized in two phases: firstly, to test the consistency in the questions, I interviewed some academic staff in the accounting department at the University of Bahrain. Also, I conducted a pilot study in some Bahrain firms to make sure that the questionnaire covers all items that would be tested; these firms were excluded from the sample. The questionnaire was revised based on the feedback received. Secondly, In order to assess the internal consistency of responses, a reliability test was made on the questionnaire responses. The Cronbach coefficient of 0.721 suggests that its internal consistency is satisfactory to design the questionnaire. The questionnaire contains two parts. Part One consisted of a number of general questions about the respondents, such as position, experience, type of industry, number of employees, total assets, and operations. For Part Two of the questionnaire, respondents had to indicate the extent to which they use fifty financial and non-financial measures in evaluating their performance. The questionnaire's items were measured using a five point Likert-type rating scale.

\section{Findings and Discussion}

The analysis is divided into two parts. In the first part responses to a series of questions that we asked both BSC adopters and BSC non-adopters are analyzed and answers of those two groups of respondents are compared. Further differentiated analysis of BSC adopters based on the firm's size. In the second part I deal with questions which I asked only BSC adopters.

Table 1. Distribution of respondents*.

\begin{tabular}{lcccc}
\hline Industry & $\begin{array}{c}\text { Adopters of } \\
\text { BSC }\end{array}$ & $\begin{array}{c}\text { Non-adopters of } \\
\text { BSC }\end{array}$ & Total & Percentage \\
\hline Chemicals & 3 & 4 & 7 & 10.1 \\
Pharmaceuti & 6 & 7 & 13 & 18.8 \\
cal \&plastic & 3 & 5 & 8 & 11.6 \\
Metal & 3 & 6 & 9 & 13.1 \\
Aluminum & 8 & 4 & 12 & 17.4 \\
Engineering & 8 & & \\
\hline
\end{tabular}




\begin{tabular}{|c|c|c|c|c|}
\hline Industry & $\begin{array}{c}\text { Adopters of } \\
\text { BSC }\end{array}$ & $\begin{array}{c}\text { Non-adopters of } \\
\text { BSC } \\
\end{array}$ & Total & Percentage \\
\hline $\begin{array}{l}\text { Food } \\
\text { processing }\end{array}$ & 6 & 5 & 11 & 15.9 \\
\hline Construction & 5 & 4 & 9 & 13.1 \\
\hline Total & 34 & 35 & 69 & 100 \\
\hline \multicolumn{5}{|c|}{$\begin{array}{l}\text { Total employees in the firm } \\
\text { Range of employees }\end{array}$} \\
\hline $\begin{array}{l}25 \text { less than } \\
100\end{array}$ & 2 & 5 & 7 & 10.1 \\
\hline $100-200$ & 9 & 14 & 23 & 33.4 \\
\hline $200-400$ & 8 & 4 & 12 & 17.4 \\
\hline $\begin{array}{l}\text { More than } \\
400\end{array}$ & 15 & 12 & 27 & 39.1 \\
\hline Total & 34 & 35 & 69 & 100 \\
\hline \multicolumn{5}{|c|}{$\begin{array}{l}\text { Total Assets of the firm } \\
\text { Range of total assets }\end{array}$} \\
\hline $\begin{array}{l}\text { Less than } \$ 1 \\
\text { Million }\end{array}$ & 4 & 12 & 16 & 23.2 \\
\hline $\begin{array}{l}\$ 1-\$ 50 \\
\text { Million }\end{array}$ & 8 & 10 & 18 & 26.1 \\
\hline $\begin{array}{l}\$ 50-100 \\
\text { Million }\end{array}$ & 6 & 6 & 12 & 17.4 \\
\hline $\begin{array}{l}\text { More than } \$ . \\
100 \text { Million }\end{array}$ & 16 & 7 & 23 & 33.3 \\
\hline Total & 34 & 35 & 69 & 100 \\
\hline
\end{tabular}

*based on the type of industry, adopters and non-adopters of BSC and firm's size by number of employees and by total assets. (BSC indicates the balanced scorecard)

Table I shows the responding firms that constitute a broad spectrum of manufacturing firms in Bahrain. The respondents were asked to answer the following question: "Is your firm using a balanced scorecard system that includes both financial and non-financial measures grouped into several perspectives (for example, financial perspective, customer's perspective, internal processes perspective, and growth \& learning perspective.)"? Subsequently, the differences were analyzed in practices between the adopters and non-adopters of balanced scorecard based on the type of industry. Also, table 1 shows total responses of firms in the target sample which adopting balanced scorecard system. It shows 34 (49.3 percent) of the respondents have already established of BSC, while 35 (50.7 percent) of the total respondents did not adopt BSC. This finding is consistent with the literature for example, Banchieri, Planas, \& Rebull, (2011) indicated that an adoption rate of BSC was in the range from $40 \%$ to $53 \%$. Furthermore, table 1 shows the effect of a firm's size on adopting BSC. The firm's size was measured in terms of number of employees and total assets. On one hand, Table 1 shows that the more the number of the employees, the more likely a firm will have BSC. About 67.6 percent $(23$ out of 34) of firms that have BSC employ more than 200 employees. More than half of the respondents that do not have BSC have less than 200 employees (19 out of 35). From this observation, we can state that usually small firms do not establish BSC perhaps because of their belief that a small firm can be controlled and governed without having to add the cost of establishing BSC. On the other hand, the firms that adopted BSC, in general, have more total assets than firms with no BSC. Approximately 47.1 percent (16 out of 34) with BSC have more than $\$ 100$ million of total assets; whilst 20 percent only with no BSC (7 out of 35 ). Naturally, the more the assets the firm owns, the more means of control and governance it needs, therefore, such firms establish BSC. When we compared the results on the basis of firm size, it is found that most of big-size firms have BSC, but most of small-size firms have no BSC. The reason of these results is that the wider and the more complicated firm; the more sophisticated performance system may be needed. Therefore, firms may have BSC, but this viewpoint will be supported by the statistical significance in the next sections. Moreover, table 1 show that BSC adopters are larger in both size measures. These results confirm my expectation that BSC adoption is highly associated with larger firms because such firms need a formalized tool for the implementation of their strategy.

\subsection{Characteristics of Performance Measurement System in Bahrain Firms}

The respondents were asked to evaluate -on a scale from one (not important) to five (very important) - the importance of various characteristics or functions of accounting performance system applied by both BSC adopters and non-adopters. Table 2 shows that all the evaluation measures which received scores above the mean of the scale are considered important in the evaluation process.

Table 2. Mean ratings of characteristics of accounting performance systems for BSC adopters and BSC non-adopters $N=69$.

\begin{tabular}{|c|c|c|c|c|c|c|}
\hline \multirow{2}{*}{ Characteristics } & \multicolumn{3}{|c|}{ BSC adopters } & \multicolumn{3}{|c|}{ BSC non-adopters } \\
\hline & Mean & SD & Rank & Mean & SD & Rank \\
\hline $\begin{array}{l}\text { Evaluates past } \\
\text { financial } \\
\text { performance }\end{array}$ & 2.88 & 1.31 & 7 & 3.84 & 0.97 & 1 \\
\hline $\begin{array}{l}\text { Enables to predict } \\
\text { future trends }\end{array}$ & 2.86 & 0.97 & 8.5 & 3.37 & 0.87 & 6 \\
\hline $\begin{array}{l}\text { Encourages a } \\
\text { positive } \\
\text { employees' } \\
\text { behavior }\end{array}$ & 3.53 & 1.02 & 5.5 & 3.64 & 1.01 & 3 \\
\hline $\begin{array}{l}\text { Supports short- } \\
\text { term decision- } \\
\text { making }\end{array}$ & 2.29 & 1.11 & 10 & 3.73 & 0.97 & 2 \\
\hline $\begin{array}{l}\text { Alignment to } \\
\text { firm's strategy }\end{array}$ & 3.75 & 1.05 & 3 & 2.45 & 1.12 & 10 \\
\hline $\begin{array}{l}\text { Is harmonized } \\
\text { with employees' } \\
\text { rewarding }\end{array}$ & 3.53 & 1.01 & 5.5 & 3.47 & 1.00 & 5 \\
\hline $\begin{array}{l}\text { Largely as a tool } \\
\text { of continuous } \\
\text { improvement }\end{array}$ & 3.81 & 1.11 & 2 & 2.86 & 1.16 & 8.5 \\
\hline $\begin{array}{l}\text { Enhances making } \\
\text { strategic } \\
\text { decisions }\end{array}$ & 3.89 & 1.06 & 1 & 3.03 & 0.98 & 7 \\
\hline $\begin{array}{l}\text { Focus of the } \\
\text { overall quality }\end{array}$ & 2.86 & 1.06 & 8.5 & 3.58 & 1.11 & 4 \\
\hline $\begin{array}{l}\text { Encourages } \\
\text { innovations }\end{array}$ & 3.71 & 1.00 & 4 & 2.86 & 1.19 & 8.5 \\
\hline
\end{tabular}


It is clear from table 2 that performance measurement system contributes to the quality of the strategic decisions in the BSC adopters make ( mean $=3.89$, rank $=1$ ) in compared with BSC non-adopters (mean $=3.03$, rank $=7$ ). Also, the system is largely as a tool of continuous improvement in the BSC adopters (mean 3.81, rank=2), but this characteristic with lower rank in BSC non-adopters (mean=2. 86, rank=8. 5). Furthermore, in the third ranking is aligned to the firm's strategy in the BSC adopters provide (mean 3.75, rank=3), while in the BSC non-adopters provide (mean= 2.45 , rank=10). Encourage innovation in the BSC adopters (mean 3.71, rank=4) and in the BSC non-adopters (mean=2. 86, rank 8.5). These findings reflect the changes in the competitive environment in Bahrain. Innovation, continuous improvement, and strategy are more important competitive factors in the BSC adopters than in the BSC non-adopters. In addition, the findings are consistent with the prior studies in the literature that BSC supports the competitive strategy of firms through providing non-financial measures. Furthermore, characteristics of performance measurement system in the BSC non-adopters reflect growing the financial performance measures. For example, the most important function of the system, in the BSC non-adopters, is to evaluate past financial performance (mean=3. 84, rank=1), then support short-term decisionmaking (mean=3. 73, rank=2), and the next encourage a positive employees' behavior (mean=3. 64 , rank=3), while the less important function is an alignment to the firm's strategy (mean=2. 45, rank=10).

Furthermore, significant differences across the average ratings of different types of characteristics were calculated based on paired t-tests at $1 \%, 5 \%$, and $10 \%$ two-tailed probability level. It was found that there is a significant difference for at least one comparison per measurement attribute. Paired t-tests between BSC adopters and nonadopters show significant difference with respect to six characteristics as shown in table 3 . These are: encourage employees' behavior $(\mathrm{t}=2.53 ; \mathrm{df}=67 ; \mathrm{p}<0.01)$, encourage innovations $(\mathrm{t}=2.72 ; \mathrm{df}=66 ; \mathrm{p}<0.01)$, alignment to the firm's strategy $(\mathrm{t}=2.14 ; \mathrm{df}=65 ; \mathrm{p}<0.05)$, as a tool of continuous improvement $(\mathrm{t}=2.23$; $\mathrm{df}=67 ; \mathrm{p}<$ $0.05)$, enhance making strategic decisions $(\mathrm{t}=2.41 ; \mathrm{df}=67$; $\mathrm{p}<0.05)$, and focus on of the overall quality $(\mathrm{t}=2.26$; $\mathrm{df}=$ $66 \mathrm{p}<0.05)$. Also, the mean values for BSC adopters are higher than for BSC non-adopters. The respondents see non-financial measures as the greatest encouragement for innovation and focusing on departmental goals. On the other hand, non-financial measures are not seen as significantly different from financial measures in their contribution to operational and strategic decision making and their capacity to align intra and interdepartmental objectives. One conclusion from the findings is that nonfinancial measures are not seen to be the least effective among types of measures along these dimensions in the BSC non-adopters. The reasons could be that these firms may be still placing greater weight on financial measures in their performance evaluation. Further differentiated analysis of BSC adopters and non-adopters were conducted to confirm these findings. Table 3 shows the findings of ANOVA. Significant differences were observed for seven characteristics. These are: As a tool of continuous improvement $(\mathrm{F}=3.03$; df $(2,64) ; \mathrm{p}<0.10)$, Encourage employees behavior $(\mathrm{F}=8.44$; df $(2,64) ; \mathrm{p}<0.01)$, An alignment to firm's strategy $(\mathrm{F}=5.41 ; \mathrm{df}(2,62) ; \mathrm{p}<0.01)$, encourages innovations $(\mathrm{F}=6.03$; df $(2,63)$; $\mathrm{p}<0.01)$, Focus on of the overall quality $(\mathrm{F}=3.48$; df $(2,63) ; \mathrm{p}$ $<0.05)$, Enhances making strategic decisions $(\mathrm{F}=3.37$; $\mathrm{df}$ (2, 64); $\mathrm{p}<0.05)$, and Harmonized with employees' rewarding $(\mathrm{F}=6.13$; df $(2,63) ; \mathrm{p}<0.01)$. Thus the first null hypothesis is rejected.

Table 3. Significant differences of the assessments of BSC adopters and non-adopters of accounting performance system.

\begin{tabular}{|c|c|c|c|c|c|c|c|}
\hline \multirow{2}{*}{ Characteristics } & \multirow{2}{*}{$\begin{array}{l}\text { Overall } \\
\text { Mean }\end{array}$} & \multirow{2}{*}{$\begin{array}{l}\text { BSC } \\
\text { adopters } \\
\text { Mean } \\
\end{array}$} & \multirow{2}{*}{$\begin{array}{l}\begin{array}{l}\text { BSC non- } \\
\text { adopters }\end{array} \\
\text { Mean } \\
\end{array}$} & \multirow{2}{*}{$\begin{array}{l}\text { T test } \\
\text { value df sig. }\end{array}$} & \multicolumn{3}{|l|}{ ANOVA } \\
\hline & & & & & F-ratio & df & sig \\
\hline Evaluate past performance & 3.82 & 4.12 & 3.67 & $1.26(67) 0.22$ & 0.83 & $(2,63)$ & 0.45 \\
\hline Enables to predict future trends & 3.87 & 4.19 & 3.80 & $1.15(66) 0.24$ & 0.64 & $(2,64)$ & 0.55 \\
\hline \multicolumn{8}{|c|}{ Has a positive impact on } \\
\hline Encourage employees' behavior & 3.71 & 4.11 & 3.42 & $2.53(67) 0.01 *$ & 8.44 & $(2,64)$ & $0.01^{*}$ \\
\hline Supports short-term decision-making & 3.21 & 3.31 & 3.10 & $0.68(67) 0.48$ & 1.22 & $(2,63)$ & 0.32 \\
\hline Helps to implement firm's strategy & 3.43 & 3.79 & 3.18 & $2.14(65) 0.03 * * *$ & 5.41 & $(2,62)$ & $0.01^{*}$ \\
\hline Harmonized with employees' rewarding & 3.09 & 3.17 & 2.95 & $0.56(66) 0.55$ & 6.13 & $(2,63)$ & $0.01 *$ \\
\hline As a tool of continuous improvement & 3.48 & 3.78 & 3.24 & $2.23(67) 0.03 * *$ & 3.03 & $(2,64)$ & $0.06^{* * *}$ \\
\hline Enhances making strategic decisions & 2.84 & 3.25 & 2.53 & $2.41(67) 0.02 * *$ & 3.37 & $(2,64)$ & $0.05^{* *}$ \\
\hline Focus on the overall quality & 2.42 & 2.88 & 2.12 & $2.26(66) 0.02 * * *$ & 3.48 & $(2,63)$ & $0.05 * *$ \\
\hline Encourages innovations & 3.72 & 4.15 & 3.40 & $2.72(66) 0.01 *$ & 6.03 & $(2,63)$ & $0.01 *$ \\
\hline
\end{tabular}

*Figures in quotation marks show number of respondents..

* Significant at 0.01 level

** Significant at 0.05 level

$* * *$ Significant at 0.10 level 


\subsection{Respondents' Preferences for the four Perspectives in the BSC Adopters}

In this section I deal with questions which asked only to the respondents in the group of BSC adopters. To examine whether the size of firm impact on adoption of BSC, the respondents were asked to evaluate the importance of financial and non-financial measures on their performance evaluation. The respondents were asked to answer the following question: "To what extent your firm uses a balanced scorecard system that includes both financial and non-financial measures grouped into four perspectives: financial perspective, customer's perspective, internal processes perspective, and growth \& learning perspective? Subsequently, the differences were analyzed in practices between different sizes of the BSC adopters. Medium and big-size firms were included in the analysis. The smallsize firms, which employed less than 100 employees, were excluded from the analysis because only two responses were received from these firms. Firms having from 100 hundred to four hundred employees are considered as medium-size and firms having more than four hundred employees considered as big-size. . Tables 4, 5, 6, and 7 shows that all the evaluation measures which received scores above the mean of the scale are considered important in the evaluation process. Furthermore, I applied a paired t-test to analyze the responses in order to see the statistical difference between different sizes of BSC adopters based on various performance measures. Significant differences are observed for five internal processes -related measures. These are: However, in the case of financial measures, the differences are found with respect to operating income $(\mathrm{t}=2.40 \mathrm{df}=66 \mathrm{p}<0.10)$, D. Material price variance $(\mathrm{t}=2.26(66) \mathrm{p}<0.05)$, D. Labor price variance $(\mathrm{t}=2.29$ (67) $\mathrm{p}<0.10)$, fixed Manf. overhead spending variance $(\mathrm{t}=2.36(67) \mathrm{p}<0.10)$, and variable Manf. overhead spending variance $(\mathrm{t}=1.77$ (67) $\mathrm{p}$ $<0.01)$. The mean values for bigger firms are higher than for the medium-sized firms. One conceivable explanation for this difference may be the resources utilized by manufacturing firms in Bahrain. It would need a huge amount of resources for bigger firms to operate their plants compared to medium-size firms. Another possible explanation for this difference could be practicing an effective control in terms of flexible budget for operating income in Bahrain firms. It would require more an effective control for the operating departments in the bigger firms than in the medium-size firms. Furthermore, significant differences are observed for seven internal processes related measures. These are: D. Material efficiency variance $(\mathrm{t}=2.04(66) \mathrm{p}<0.05)$, D. Labor efficiency variance $(\mathrm{t}=1.72(67) \mathrm{p}<0.10)$, fixed Manf. overhead efficiency variance $(\mathrm{t}=2.51(67) \mathrm{p}<0.01)$, and variable Manf. overhead efficiency variance $(\mathrm{t}=1.99(67) \mathrm{p}<0.10)$, Defect rate $(\mathrm{t}=2.16(65) \mathrm{p}<0.05)$, Set-up and changeover time $(\mathrm{t}=2.74(66) \mathrm{p}<0.01)$, and Manf. Lead time/cycle time $(\mathrm{t}=1.65(66) \mathrm{p}<0.10)$. The mean values for bigger firms are higher than for medium-size firms. One probable explanation for this difference may be the bigger firms have a huge amount of resources and they may need to measure the efficiency of utilizing resources in comparison with the medium-size firms. Another explanation that is perhaps the Bahrain environment become more competitive and the cost-leadership strategy requires that the biggest firms reduce the cost of their products. The difference in the defect rate is an indication of the product quality for bigger firms may be more effective than in the medium sized firms. The differences are found with respect to three learning and growth-related measures. The employee empowerment $(\mathrm{t}=2.31$ (65) $\mathrm{p}<0.10)$. The employee training $(\mathrm{t}=2.52(65) \mathrm{p}<0.10)$, and the level of absenteeism $(t=3.13 ; \mathrm{df}=66 ; \mathrm{p}<0.01)$. The mean scores are higher for bigger-sized firms than medium -size firms. The possible explanation for this difference may be that, in big firms, it obvious that supervision is more governance and more powerful given to employees in decision making. Also, the biggest firms may be interesting to raise the skills of their employees through adopting continuous training programs. Three statistical differences are found with respect to market share $(\mathrm{t}=2.19 ; \mathrm{df}=66 ; \mathrm{p}<0.10)$, customer complaints $(\mathrm{t}=2.28 ; \mathrm{df}=66 ; \mathrm{p}<0.01)$, and warranty claims $(\mathrm{t}=2.49 ; \mathrm{df}=66 ; \mathrm{p}<0.05)$. Again the mean values are higher for medium-size than for bigger firms. The difference may be an indication of the product quality for bigger firms may be more effective than in medium sized firms. Thus the second null hypothesis is rejected. It observes that the bigger firm's size, the more complex business lines, and the need for more effective control. Therefore the big-size firms need to adopt a sophisticated multiple measurement system to evaluate the performance.

ANOVA is used to analyze data by number of employees. Significant differences are observed for five measures with respect to internal processes -related measures. These are: variable Manf. overhead efficiency variance $(\mathrm{F}=3.03$; df $(2,64) ; \mathrm{p}<0.10)$, fixed Manf. overhead efficiency variance $(\mathrm{F}=7.43 ; \mathrm{df}(2,64) ; \mathrm{p}<0.01)$, Defect rate $(\mathrm{F}=4.42 ; \mathrm{df}(2,62) ; \mathrm{p}<0.01)$, Set-up and changeover time $(\mathrm{F}=5.07$; $\mathrm{df}(2,63) ; \mathrm{p}<0.01)$, and Manf. lead time/cycle time $(\mathrm{F}=3.49 ; \mathrm{df}(63,2) ; \mathrm{p}<0.10)$. Only two significant differences are found for financial measures. Total manufacturing costs $(\mathrm{F}=3.12$; df $(2,63)$; $\mathrm{p}<0.10)$, and RIO (F = 4.54; df $(2,64) ; \mathrm{p}<0.01)$. Similarly, level of absenteeism, $(\mathrm{F}=5.69 ; \mathrm{df}(2,63) ; \mathrm{P}<0.01)$, and employees' skills $(\mathrm{F}=3.14$; df $(2,64) ; \mathrm{P}<0.05)$, respectively, are among learning and growth-related measures This shows that when the size of firm differs, the financial and non-financial measures differ because of the mix of products and the complex of operations in the bigsize firms. 
Table 4. Significant differences of BSC adopters' assessments of financial perspective importance for performance evaluation.

\begin{tabular}{|c|c|c|c|c|c|c|c|}
\hline \multirow{3}{*}{ Financial measures } & \multicolumn{4}{|c|}{ BSC adopters } & \multicolumn{3}{|c|}{ By number of employees ANOVA } \\
\hline & Overall & $\begin{array}{l}\text { Big-size } \\
\text { firms }\end{array}$ & $\begin{array}{c}\text { Medium-size } \\
\text { firms }\end{array}$ & value df sig & F-ratio & df & sig. \\
\hline & Mean & Mean & Mean & & & & \\
\hline Operating income & 3.84 & 3.77 & 3.88 & $2.40(66) 0.69^{* * *}$ & 1.68 & $(2,63)$ & 0.52 \\
\hline Sales growth & 3.72 & 3.79 & 3.71 & $0.06(65) 0.92$ & 1.87 & $(2,62)$ & 1.87 \\
\hline Sales revenue & 3.60 & 3.81 & 3.43 & $1.40(65) 0.15$ & 1.93 & $(2,62)$ & 0.17 \\
\hline Return on investment (ROI) & 3.47 & 3.51 & 3.23 & $0.89(67) 0.38$ & 4.64 & $(2,64)$ & $0.01 *$ \\
\hline Total net cash flow & 3.46 & 3.61 & 3.05 & 0.77 (66) 0.45 & 1.17 & $(2,63)$ & 0.33 \\
\hline Total manufacturing costs & 3.41 & 3.46 & 3.20 & $1.01(66) 0.33$ & 3.12 & $(2,63)$ & $0.05^{* *}$ \\
\hline Cost of goods sold & 3.44 & 3.41 & 3.42 & 0.07 (66) 0.96 & 0.85 & $(2,63)$ & 0.45 \\
\hline D. material price variance & 3.43 & 3.52 & 3.31 & $2.26(66) 0.04 * *$ & 0.69 & $(2,63)$ & 0.52 \\
\hline D. labor price variance & 3.40 & 3.54 & 3.24 & $2.29(67) 0.37 * * *$ & 1.17 & $(2,64)$ & 0.33 \\
\hline F. Manf. overhead spending variance & 3.36 & 3.58 & 3.42 & $2.36(67) 0.71 * * *$ & 0.57 & $(2,64)$ & 0.49 \\
\hline V. Manf. overhead spending variance & 3.25 & 3.52 & 3.35 & $1.77(67) 0.01 *$ & 1.04 & $(2,64)$ & 0.37 \\
\hline
\end{tabular}

*Figures in quotation marks show number of respondents.

* Significant at 0.01 level

** Significant at 0.05 level

*** Significant at 0.10 level

Table 5. Significant differences of BSC adopters' assessments of internal processes perspective importance for performance evaluation.

\begin{tabular}{|c|c|c|c|c|c|c|c|}
\hline \multirow{3}{*}{$\begin{array}{l}\text { Internal processes-related } \\
\text { measures }\end{array}$} & \multicolumn{4}{|c|}{ BSC adopters } & \multicolumn{3}{|c|}{ By number of employees ANOVA } \\
\hline & \multirow{2}{*}{$\begin{array}{c}\text { Overall } \\
\text { Mean }\end{array}$} & \multirow{2}{*}{$\frac{\text { Big-size firms }}{\text { Mean }}$} & \multicolumn{2}{|l|}{ Medium-size firms } & \multirow{2}{*}{ F-ratio } & \multirow{2}{*}{ df } & \multirow{2}{*}{ sig } \\
\hline & & & Mean & value df sig & & & \\
\hline D. material efficiency variance & 3.90 & 4.22 & 3.82 & $2.04(66) 0.05 * *$ & 0.65 & $(2,64)$ & 0.52 \\
\hline D. labor efficiency variance & 3.81 & 4.00 & 3.66 & $1.72(67) 0.09 * * *$ & 1.10 & $(2,64)$ & 0.33 \\
\hline $\begin{array}{l}\text { V. Manf. overhead efficiency } \\
\text { variance }\end{array}$ & 3.81 & 4.09 & 3.69 & $1.99(67) 0.21 * * *$ & 3.03 & $(2,64)$ & $0.06^{* * *}$ \\
\hline $\begin{array}{l}\text { F. Manf. overhead efficiency } \\
\text { variance }\end{array}$ & 3.73 & 4.13 & 3.44 & $2.51(67) 0.01 *$ & 7.43 & $(2,64)$ & $0.01 *$ \\
\hline Sales volume variance & 3.64 & 3.71 & 3.60 & $0.37(66) 0.69$ & 1.95 & $(2,63)$ & 0.17 \\
\hline Rate of material scrap loss & 3.19 & 3.33 & 3.12 & $0.70(66) 0.49$ & 1.19 & $(2,63)$ & 0.30 \\
\hline Defect rate & 3.41 & 3.80 & 3.20 & $2.16(65) 0.03 * *$ & 4.42 & $(2,62)$ & $0.01 *$ \\
\hline Set-up and changeover time & 3.69 & 4.17 & 3.42 & $2.74(66) 0.01 *$ & 5.07 & $(2,63)$ & $0.01^{*}$ \\
\hline $\begin{array}{l}\text { Material and changeover } \\
\text { flexibility }\end{array}$ & 3.27 & 3.39 & 3.17 & $0.77(64) 0.44$ & 0.65 & $(2,61)$ & 0.57 \\
\hline Manf. lead time/cycle time & 2.67 & 2.96 & 2.35 & $1.65(66) 0.09 * * *$ & 3.49 & $(2,63)$ & $0.06 * * *$ \\
\hline
\end{tabular}

*Figures in quotation marks show number of respondents..

* Significant at 0.01 level

** Significant at 0.05 level

*** Significant at 0.10 level

Table 6. Significant differences of BSC adopters' assessments of learning \& growth perspective importance for performance evaluation.

\begin{tabular}{|c|c|c|c|c|c|c|c|}
\hline \multirow{3}{*}{ Characteristics } & \multirow{3}{*}{$\begin{array}{c}\text { Overall } \\
\text { Mean }\end{array}$} & \multirow{3}{*}{$\begin{array}{c}\text { BSC adopters } \\
\text { Mean }\end{array}$} & \multirow{3}{*}{$\begin{array}{c}\begin{array}{c}\text { BSC non- } \\
\text { adopters }\end{array} \\
\text { Mean }\end{array}$} & \multirow{3}{*}{$\frac{T \text { test }}{\text { alue df sig. }}$} & \multicolumn{3}{|c|}{ ANOVA } \\
\hline & & & & & \multirow[t]{2}{*}{ F-ratio } & \multirow[t]{2}{*}{ df } & \multirow[t]{2}{*}{ sig } \\
\hline & & & & & & & \\
\hline Evaluate past performance & 3.82 & 4.12 & 3.67 & $1.26(67) 0.22$ & 0.83 & $(2,63)$ & 0.45 \\
\hline Enables to predict future trends & 3.87 & 4.19 & 3.80 & $1.15(66) 0.24$ & 0.64 & $(2,64)$ & 0.55 \\
\hline \multicolumn{8}{|l|}{ Has a positive impact on } \\
\hline Encourage employees' behavior & 3.71 & 4.11 & 3.42 & $2.53(67) 0.01 *$ & 8.44 & $(2,64)$ & $0.01 *$ \\
\hline Supports short-term decision-making & 3.21 & 3.31 & 3.10 & $0.68(67) 0.48$ & 1.22 & $(2,63)$ & 0.32 \\
\hline Helps to implement firm's strategy & 3.43 & 3.79 & 3.18 & $2.14(65) 0.03 * * *$ & 5.41 & $(2,62)$ & $0.01 *$ \\
\hline Harmonized with employees' rewarding & 3.09 & 3.17 & 2.95 & $0.56(66) 0.55$ & 6.13 & $(2,63)$ & $0.01 *$ \\
\hline As a tool of continuous improvement & 3.48 & 3.78 & 3.24 & $2.23(67) 0.03 * *$ & 3.03 & $(2,64)$ & $0.06 * * *$ \\
\hline Enhances making strategic decisions & 2.84 & 3.25 & 2.53 & $2.41(67) 0.02 * *$ & 3.37 & $(2,64)$ & $0.05 * *$ \\
\hline Focus on the overall quality & 2.42 & 2.88 & 2.12 & $2.26(66) 0.02 * * *$ & 3.48 & $(2,63)$ & $0.05^{* *}$ \\
\hline Encourages innovations & 3.72 & 4.15 & 3.40 & $2.72(66) 0.01 *$ & 6.03 & $(2,63)$ & $0.01 *$ \\
\hline
\end{tabular}

*Figures in quotation marks show number of respondents.

* Significant at 0.01 level

** Significant at 0.05 level

*** Significant at 0.10 level 
Table 7. Significant differences of BSC adopters' assessments of customer perspective importance for performance evaluation.

\begin{tabular}{|c|c|c|c|c|c|c|c|}
\hline \multirow{3}{*}{ Customer-related measures } & \multicolumn{4}{|c|}{ BSC adopters } & \multicolumn{3}{|c|}{ By number of employees ANOVA } \\
\hline & \multirow{2}{*}{$\begin{array}{c}\text { Overall } \\
\text { Mean } \\
\end{array}$} & \multirow{2}{*}{$\begin{array}{c}\text { Big-size firms } \\
\text { Mean }\end{array}$} & \multicolumn{2}{|l|}{ Medium-size firms } & \multirow{2}{*}{ F-ratio } & \multirow{2}{*}{ df } & \multirow[b]{2}{*}{ sig. } \\
\hline & & & Mean & value df sig. & & & \\
\hline Market share & 3.51 & 3.67 & 3.36 & $2.19(66) 0.28^{* * *}$ & 0.08 & $(2,63)$ & 0.90 \\
\hline On-time delivery & 3.86 & 3.88 & 3.78 & $0.34(66) 0.75$ & 0.26 & $(2,63)$ & 0.75 \\
\hline No. of customer orders completed & 4.16 & 4.25 & 4.06 & $0.73(67) 0.46$ & 0.56 & $(2,64)$ & 0.55 \\
\hline Customer response time & 3.92 & 3.78 & 3.71 & 1.09 (66) 0.29 & 1.07 & $(2,63)$ & 0.35 \\
\hline Customer complaints & 3.82 & 3.95 & 3.67 & $2.28(66) 0.01^{*}$ & 0.27 & $(2,63)$ & 0.76 \\
\hline Customer satisfaction & 4.22 & 4.24 & 4.15 & $0.33(67) 0.72$ & 1.72 & $(2,64)$ & 0.18 \\
\hline Warranty claims & 3.03 & 3.52 & 2.51 & $2.49(66) 0.02 * *$ & 1.13 & $(2,63)$ & 0.34 \\
\hline No. of customer orders received & 3.42 & 3.67 & 3.25 & $1.44(66) 0.17$ & 0.68 & $(2,63)$ & 0.52 \\
\hline Customer loyalty & 3.44 & 3.67 & 3.29 & $1.45(66) 0.16$ & 0.07 & $(2,63)$ & 0.93 \\
\hline
\end{tabular}

*Figures in quotation marks show number of respondents.

* Significant at 0.01 level

** Significant at 0.05 level

$* * *$ Significant at 0.10 level

\section{Conclusions and Implications}

This study investigated the extent to which manufacturing firms in Bahrain adopt the balanced scorecard in their performance evaluation. Also, this study statistically examined the effect of a firm's size on adopting balance scorecard in Bahrain. Therefore, this study adds value to the literature of performance measurement by exploring the practices of performance measurement in such a developing country as Bahrain. The findings confirmed the null hypotheses that there are statistical differences between the manufacturing firms in Bahrain in adopting a balanced scorecard. Also the results supported that there is effect of the firm's size on the growing use of non-financial measures in comparison with the financial measures in the BSC adopters. However, my findings in this study show that the respondents in the BSC adopting firms have been selected, implementing and integrating the use of appropriate measures. They perceive that the chosen performance measures affect the performance of their employees. Furthermore, my findings may be used to motivate the BSC non-adopting firms to use of the non-financial performance measures.

However, my findings confirmed the hypothesis that the size of firms also affects adopting the BSC. It is observed in this study that there are significant differences between firms in the target sample in selecting financial and non-financial measures.

\section{Limitations of Study and Future Research Directions}

It is important to emphasize that the findings of this study should be interpreted and evaluated in light of the data collected from the target sample firms and in the light of the limitation that also relate to future research directions. The sample was taken only from the MCI directory where the population is limited to only the manufacturing firms that are members of the association. Thus, the sample was relatively small and not necessarily comprehensive. Also, this study was limited to the sample which taken randomly only from manufacturing firms. This could provide a potential source of bias to generalize the findings. Thus, future research should study larger sample size using industries beyond manufacturing.

One subject in the direction of further research in this area that is adopting BSC affect by the differences between various industries. Finally, additional research on business strategies and performance measurement is needed in Bahrain. Much can be learned from the progress that has been made during the last few decades. In many respects, for example, findings from the present study lend support to previous work on the BSC and performance measures. Nonetheless, additional work is needed to clarify how firm behavior in Bahrain compares and contrasts to the developed countries.

\section{Acknowledgement}

The author appreciates the assistance provided by the accounting staff in the University of Bahrain (UOB) to design the questionnaire. Also, I thank the chief executive officers (CEOs) and financial controllers who participated in this study to collect data from the Bahrain sample firms. A special thanks to anonymous referees for helpful suggestions.

\section{References}

[1] Banchieri, L., Planas, F. \& Rebull, M. (2011). What has been said, and what remains to be said, about the balanced scorecard? Zbornik Radova Ekonomski Fakultet u Rijeka, 29 (1), 155-192.

[2] Bititci, U. S., Garengo, P., Dörfler, V. \& Nudurupati, S. (2011). Performance measurement: Challenges for tomorrow. International Journal of Management Reviews, 14 (3), 305-327.

[3] Burkert, M., Davila, A. \& Oyon, D. (2010). Performance consequences of balanced scorecard adoptions: Claim for large-scale evidence and propositions for future research. In Epstein, M.C., Manzoni, J-F., \& Davila, A. (Eds.), Performance measurement and management control: innovative concepts and practices (pp. 345-361). 
[4] Fernandes, K., Raja, V. and Whalley, A. (2006), "Lessons from implementing the Balanced Scorecard in a small and medium size manufacturing organization", Technovation, Vol. 26, pp. 623-624.

[5] Ferreira, A. \& Otley, D. (2009). The design and use of performance management systems: An extended framework for analysis. Management Accounting Research, 20 (4), 263-282.

[6] Garengo, P., Biazzo, S. \& Bititci, U. S. (2005). Performance measurement systems in SMEs: A review for a research agenda. International Journal of Management Reviews, 7 (1), $25-47$.

[7] Gumbus, A. and Lussier, R.N. (2006) 'Entrepreneurs use a balanced scorecard to translate strategy into performance measures', Journal of Small Business Management, Vol. 44 , No. 3, pp. 407-425.

[8] Hayes, Robert H., (1981). "Why Japanese Factories Work," Harvard Business Review (July- August, pp. 57-66.

[9] Hoque, Z. \& James, W. (2000). Linking balanced scorecard measures to size and market factors: Impact on organizational performance. Journal of Management Accounting Research, 12 (1), 1-17.

[10] Hvolby, H.H. and Thorstenson, A. (2001) 'Indicators for performance measurement in small and medium sized enterprises', Proceedings of the Institution of Mechanical Engineers, Part B, Vol. 215, pp. 1143-1146.

[11] Kaplan, R. S. \& Norton, D. P. (2008). Execution premium: Linking strategy to operations for competitive advantage. Boston, Mass.: Harvard Business School Press Books.

[12] Kaplan, R. S. \& Norton, D. P. (2006). Alignment: Using the balanced scorecard to create corporate synergies. Boston, Mass.: Harvard Business School Press.

[13] Kaplan, R. S. (2005). How the balanced scorecard complements the McKinsey 7-S model. Strategy \& Leadership, 33 (3), 41-46.

[14] Kaplan, R. S. \& Norton, D. P. (2000). The strategy-focused organization: How balanced scorecard companies thrive in the new business environment. Boston: Harvard Business School Press.

[15] Kaplan, R. S. \& Norton, D. P. (1996a). Using the balanced scorecard as a strategic management system. Harvard Business Review, 74 (1), 75-85.

[16] Kaplan, R. S. \& Norton, D. P. (1996b). The balanced scorecard: Translating strategy into action. Boston, Mass.: Harvard Business School Press.

[17] Kaplan, R. S. \& Norton, D. P. (1993). Putting the balanced scorecard to work. Harvard Business Review, 71 (5), 134147.

[18] Kaplan, R. S. \& Norton, D. P. (1992). The balanced scorecard - measures that drive performance. Harvard Business Review, 70 (1), 71-79.
[19] Malmi, T. (2001), "Balanced Scorecards in Finnish companies: a research note", Management Accounting Research, Vol. 12 No. 2, pp. 207-220.

[20] Manville, G. (2007), "Implementing a Balanced Scorecard framework in a not for profit SME, “International Journal of Productivity and Performance Management, Vol. 56 No. 2, pp. 162-169.

[21] Marr, B. and Schiuma, G. (2003), "Business performance measurement - past, present and future", Management Decision, Vol. 41 No. 8, pp. 680-687.

[22] Merchant, K.A. (1981) 'The design of corporate budgeting system: Influence on managerial behavior and performance', Accounting Review, Vol. 56, No. 4, pp.813-829.

[23] Neely, A. (2005). The evolution of performance measurement research: Developments in the last decade and a research agenda for the next. International Journal of Operations \& Production Management, 25 (12), 1264-1277.

[24] Neely, A., Gregory, M. \& Platts, K. (1995). Performance measurement system design. A literature review and research agenda. International Journal of Operations \& Production Management.

[25] Perera, P. and Baker, P. (2007) 'Performance measurement practices in small and medium size manufacturing enterprises in Australia', Small Enterprise Research, Vol.15, No.2, pp. 10-32.

[26] Phillips, B., Wee, T.T.T. and Shanka, T. (2003) 'The use of performance measures in small and medium enterprises (SMEs) - an exploratory study', Working paper, Curtin Business School, Australia, available at http://smib.vuw.ac.nz:8081/WWW/ANZMAC2003/papers/S T14_phillipsb.pdf

[27] Rigby, D. (2011), "Management tools and trends 2011", available at: www.bain.com/ management tools/home.asp (accessed 6 June 2011).

[28] Schonberger, Richard, (1982), Japanese Manufacturing Techniques (New York: Free Press, Richardson, Peter R. and John R. M. Gordon, "Measuring Total Manufacturing Performance," Sloan Management Review (Winter 1980), pp. $47-58$

[29] Silk, S. (1998), Automating the Balanced Scorecard", Management Accounting, Vol. 11, pp. 38-44.

[30] Speckbacher, G., Bischof, J. and Pfeiffer, T. (2003), “A descriptive analysis on the implementation of Balanced Scorecards in German-speaking countries", Management Accounting Research, Vol. 14 No. 4, pp. 361-387.

[31] Taylor and Baines' study (2012), "Performance management in UK universities: implementing the Balanced Scorecard", Journal of Higher Education Policy and Management, Vol. 34 No. 2, pp. 111-124.

[32] The Ministry of Commerce and Industry, Bahrain (http://www.industry.gov.bh/english/). 